\title{
ELANE Gene
}

National Cancer Institute

\section{Source}

National Cancer Institute. ELANE Gene. NCI Thesaurus. Code C104195.

This gene plays a role in innate host defense. 